\title{
First report of detection of Toxoplasma gondii DNA in oysters (Crassostrea sp.) in the state of Maranhão
}

\author{
Primeiro relato da detecção de DNA de Toxoplasma gondii em ostras \\ (Crassostrea sp.) no Estado do Maranhão
}

\begin{abstract}
Camila Moraes Silva; Anna Letícia Pinto Silva²; Karinne Francisca Cardoso Watanabe; Nancyleni Pinto Chaves Bezerra ${ }^{1,2,3 *}$ (1); Danilo Cutrim Bezerra2; Hugo Moreira Gomes3; Thais Brito Freire ${ }^{3}$; Larissa Sarmento dos Santos ${ }^{1,4}$; Alcina Vieira de Carvalho Neta ${ }^{5,6}$; Ellainy Maria Conceição Silva ${ }^{4}$; Viviane Correia Silva Coimbra ${ }^{1,4}$
\end{abstract}

\begin{abstract}
'Programa de Pós-graduação Profissional em Defesa Sanitária Animal, Universidade Estadual do Maranhão - UEMA, São Luís, MA, Brasil ${ }^{2}$ Curso de Zootecnia, Departamento de Zootecnia, Universidade Estadual do Maranhão - UEMA, São Luís, MA, Brasil ${ }^{3}$ Curso de Engenharia de Pesca, Departamento de Engenharia de Pesca, Universidade Estadual do Maranhão - UEMA, São Luís, MA, Brasil ${ }^{4}$ Curso de Medicina Veterinária, Departamento de Patologia, Universidade Estadual do Maranhão - UEMA, São Luís, MA, Brasil ${ }^{5}$ Curso de Biologia, Departamento de Biologia, Universidade Estadual do Maranhão - UEMA, São Luís, MA, Brasil ${ }^{6}$ Programa de Pós-graduação em Ciência Animal, Universidade Estadual do Maranhão - UEMA, São Luís, MA, Brasil
\end{abstract}

How to cite: Silva CM, Silva ALP, Watanabe KFC, Bezerra NPC, Bezerra DC, Gomes HM, et al. First report of detection of Toxoplasma gondii DNA in oysters (Crassostrea sp.) in the state of Maranhão. Braz J Vet Parasitol 2020; 29(3): e003720. https://doi.org/10.1590/ S1984-29612020050

\begin{abstract}
The aim of this study was to report on detection of Toxoplasma gondii DNA in oysters (Crassostrea sp.) in the state of Maranhão. To conduct this study, 200 farmed oysters were acquired in the municipality of Raposa and 100 in Paço do Lumiar; and a further 100 oysters were taken from the natural stock in the municipality of Primeira Cruz. This total of 400 specimens sampled was divided into 80 pools composed of five animals each. The gills and visceral mass of each oyster were removed for DNA extraction (per pool of oysters), using a commercial kit. The nested PCR technique (with the primer SAG-1) was then used to investigate any presence of protozoa. This molecular technique demonstrated the presence of DNA of T. gondii in $2.5 \%$ of the pools of oysters $(n=2 / 80)$ : these oysters were exclusively from farms. The results from this study allow the conclusion that oysters of the genus Crassostrea that are farmed in the state of Maranhão are capable of filtering oocysts of $T$. gondii and maintaining them in their tissues. They are therefore potential sources of contamination for humans and other animals.
\end{abstract}

Keywords: Bivalve mollusk, toxoplasmosis, molecular biology.

\section{Resumo:}

Objetivou-se com este estudo relatar a detecção do DNA de Toxoplasma gondii em ostras (Crassostrea sp.) no estado do Maranhão. Para a realização do estudo foram adquiridas 200 ostras de cultivo do município de Raposa, e 100 de Paço do Lumiar, além de 100 ostras extraídas de estoque natural do município de Primeira Cruz. Do total de 400 exemplares amostrados, formaram-se 80 pools em que cada pool foi constituído por cinco animais. De cada ostra foi procedida à retirada das brânquias e massa visceral, seguido da extração de DNA de cada pool de ostras, com a utilização de kit comercial. Posteriormente, realizou-se a pesquisa do protozoário por meio da técnica de nested PCR (primer SAG-1). Com a técnica molecular utilizada, foi diagnosticado o DNA do protozoário pesquisado em 2,5\% ( $n=2 / 80$ ) pools de ostras oriundas exclusivamente de cultivo. Com os resultados obtidos neste estudo, conclui-se que ostras do gênero Crassostrea sp., cultivadas no estado do Maranhão, são capazes de filtrar e manter nos seus tecidos oocistos de $T$. gondii, sendo, portanto, fontes potenciais de contaminação para seres humanos e outros animais.

Palavras-chave: Molusco bivalve, toxoplasmose, biologia molecular. 


\section{Introduction}

Toxoplasma gondii is the etiological agent of toxoplasmosis, a disease that has worldwide distribution and which can infect all warm-blooded vertebrates, including humans (Dubey, 2010). It has been estimated that more than a third of the human population is infected with T. gondii (Djurković-Djaković et al., 2019).

Ferreira et al. (2013) stated that transmission of $T$. gondii to humans can occur at three developmental stages of this protozoon: (i) from sporulated oocysts, orally through intake of water or food contaminated with oocysts that are present in the environment and are eliminated in the feces of young felids; (ii) from bradyzoites, orally through ingestion of tissue cysts in raw and undercooked meat originating from intermediate hosts; and, (iii) from tachyzoites, through vertical transplacental transmission.

Improper disposal of domestic sewage and industrial effluents and dispersal of residual water containing feces from domestic animals and humans are potential causes of contamination of the environment by protozoa of the phylum Apicomplexa, like T. gondii. Therefore, use of contaminated water and mollusks is an important point to be considered from a public health point of view, in studies on zoonotic protozoa (Giangaspero et al., 2014; Sutthikornchai et al., 2016).

The cosmopolitan distribution of oysters, along with their sessile living habit and the efficiency of their filtration compartment, makes them capable of bioaccumulation of pollutants, including heavy metals, hydrocarbons, chlorinated hydrocarbons, microplastics, radionuclides and parasites from human and animal waste. Consequently, they are considered to be excellent beacons for monitoring the health of estuarine ecosystems (Palos Ladeiro et al., 2013; Marquis et al., 2019; Gyawali \& Hewitt, 2020).

T. gondii was detected in oysters (Crassostrea gigas) under cultivation in Lago di Varano (southern Italy), by means of nested PCR and real-time PCR (Putignani et al., 2011); and in oysters (Crassostrea virginica) on the coast of Maine (USA), by means of quantitative PCR (Marquis et al., 2019). In Brazil, using nested PCR, the parasite was identified in oysters (Crassostrea rhizophorae) that were destined for sale and consumption in fish markets in São Paulo (Esmerini et al., 2010), and that were obtained from the southern coastal region of Bahia (Ribeiro et al., 2015).

Oysters are considered to be a delicacy worldwide, including in Brazil, and can be harvested either from natural beds or from cultivations (Souza et al., 2012; Giangaspero et al., 2014). The Brazilian state of Maranhão has a very long coastline (approximately $640 \mathrm{~km}$ in length), which gives it major potential for development of oyster aquaculture. Estuarine areas along the coast of Maranhão present natural occurrences of two native oyster species in the genus Crassostrea (França et al., 2013): C. gasar and C. rhizophorae (Lopes et al., 2018).

Monitoring occurrences of zoonotic protozoa in oysters is important for ascertaining whether their consumption might present a risk to human health. Moreover, such occurrences may serve as bioindicators or contamination. In this light, the present study was conducted with the aim of detecting the DNA of T. gondii in oysters (Crassostrea sp.) in the state of Maranhão.

\section{Material and Methods}

The study location was chosen as a function of where in the state of Maranhão activities of extraction and farming of oysters are conducted. Thus, the oysters used in this study were acquired from seafood farmers in the municipalities of Paço do Lumiar $\left(02^{\circ} 31^{\prime} \mathrm{S}\right.$ and $\left.44^{\circ} 06^{\prime} \mathrm{W}\right)$ and Raposa $\left(02^{\circ} 25^{\prime} \mathrm{S}\right.$ and $\left.44^{\circ} 06^{\prime} \mathrm{W}\right)$ and from seafood gatherers in the municipality of Primeira Cruz ( $02^{\circ} 33^{\prime} \mathrm{S}$ and $43^{\circ} 21^{\prime} \mathrm{W}$ ) (Figure 1).

After acquisition, the oysters were transported in plastic bags that were kept in cooler boxes with recyclable ice, for not more than 12 hours, to the physicochemical laboratory for food and water of the State University of Maranhão (UEMA). In this laboratory, the external surfaces of the oyster shells were washed with distilled water and any epibionts were removed with the aid of cutting and drilling instruments and brushes.

Between September and December 2018, 400 live specimens of oysters were acquired: 200 from farms in Raposa, 100 from farms in Paço do Lumiar and 100 from the natural stock in Primeira Cruz. These were grouped into 80 pools of five animals each. The sampling design of this study followed the protocol proposed by Esmerini et al. (2010). From each pool, the gills and the region of the digestive glands (named the "visceral mass" for the purposes of this study) were removed. This protocol resulted in formation of two sample groups of 80 pools each, thus now totaling 160 pools: (i) 80 pools for the gill group; and (ii) 80 pools for the visceral mass group. 


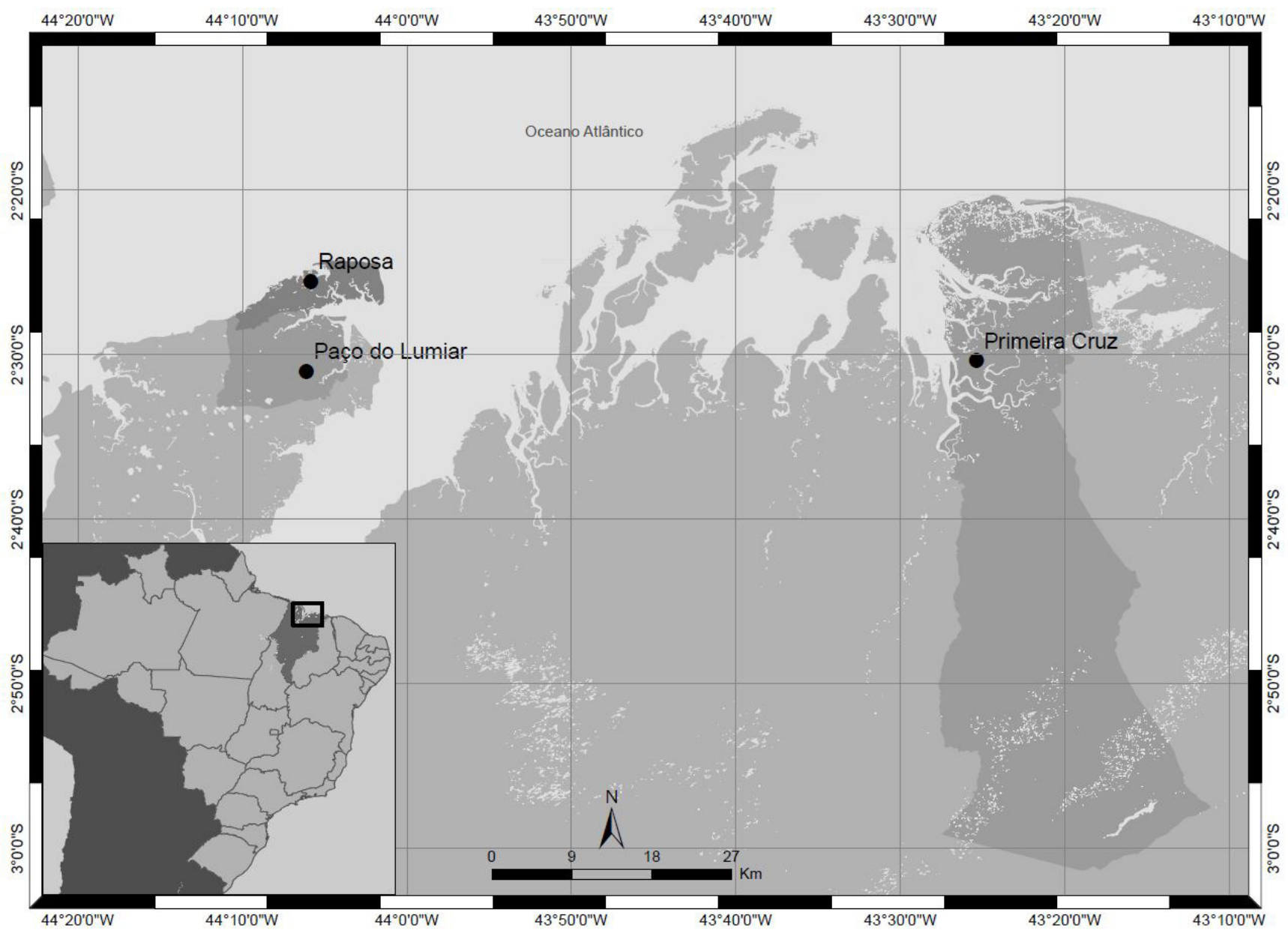

Figure 1. Oyster collection sites in the state of Maranhão.

The animals were measured to obtain their height (the distance between the umbo and the posterior extremity of the shell) and length, using calipers with a precision to the nearest $0.01 \mathrm{~mm}$. They were then weighed to determine the total mass, on a digital scale with precision to the nearest $0.001 \mathrm{~g}$.

Groups of five animals were formed based on these animals' similarity of morphometric characteristics and were numbered. The oyster valves were then opened with the aid of a knife and the oysters were removed from their shells and weighed on a digital scale with precision to the nearest $0.001 \mathrm{~g}$. Next, with the aid of scissors, the gills and portions of the visceral mass were removed and weighed. The pools, as described above, were then stored at $-20^{\circ} \mathrm{C}$, separately in $1.5 \mathrm{~mL}$ microtubes that were duly identified.

Subsequently, the samples were defrosted and the tissues (gills and visceral mass) of the sampling groups were macerated in a mortar using a pestle. Thus, each sample consisted of either gill tissue or visceral mass from five animals. Next, aliquots of approximately $0.5 \mathrm{~mL}$ were placed in sterile microtubes of capacity $2 \mathrm{~mL}$ and these were stored at $-20^{\circ} \mathrm{C}$ until the time of extraction of deoxyribonucleic acid (DNA).

The steps of the DNA extraction and the polymerase chain reaction (PCR) were performed in the molecular biology laboratory that forms part of the multiuse postgraduate laboratory of UEMA. These procedures were done between January and March 2019.

The Wizard ${ }^{\circledR}$ genomic DNA purification kit (Promega) was used for DNA extraction in accordance with the manufacturer's guidelines, with some adaptations regarding the sample amounts (approximately $1 \mathrm{~g}$ ) and the process for breaking the oocyst wall (1 g glass beads were used).

The DNA concentrations of the samples were determined using a spectrophotometer and were adjusted with Tris-EDTA pH 8.0 (TE) to $200 \mathrm{ng} / \mu \mathrm{L}$. The samples were then stored at $-20^{\circ} \mathrm{C}$ until the time of performing the semi-nested PCR technique. 
The DNA was investigated using the nested PCR method with the primer SAG-1 (external primers: F1: 5'-GTTCTAACCACGCACCCTGAG-3'; R: 5'-AAGAGTGGGAGGCTCTGTGA-3'; and internal primers: F2: 5'-CAATGTGCACCTGTAGGAAGC-3'; R2: 5'-GTGGTTCTCCGTCGGTGTGAG-3'). This amplified a fragment of 390 base pairs (bp) of the DNA of T. gondii, as described by Ribeiro et al. (2015).

The first round of PCR was performed with $5 \mu \mathrm{L}$ DNA extracted DNA and a $20 \mu \mathrm{L}$ reaction mixture $[0.25 \mathrm{mM}$ of each primer, $0.2 \mathrm{mM}$ of dNTP (PROMEGA $\left.{ }^{\circledR}\right), 1 \times$ Tris $\mathrm{HCl}, 3.0 \mathrm{mM}$ of $\mathrm{MgCl}_{2}$ and $1.25 \mathrm{U}$ of Taq DNA polymerase (PROMEGA $\left.{ }^{\circledR}\right)$ ]. Parasite DNA amplification was performed under the following conditions: $5 \mathrm{~min}$ at $94^{\circ} \mathrm{C}$ for denaturing; 35 cycles of $1 \mathrm{~min}$ at $94^{\circ} \mathrm{C}$ for denaturing, $1 \mathrm{~min}$ at $58^{\circ} \mathrm{C}$ for annealing and $1 \mathrm{~min}$ at $72^{\circ} \mathrm{C}$ for extension and a final extension at $72{ }^{\circ} \mathrm{C}$ for $10 \mathrm{~min}$. A $2-\mu \mathrm{L}$ aliquot of the PCR product was used in the nested PCR performed using the secondary primers. The second round of PCR was carried out under the same cycling conditions as the first.

A positive control (DNA of $T$. gondii that was made available by the multiuse laboratory) was added to each amplification batch, along with a negative control consisting of ultrapure water.

Aliquots of $5.0 \mu \mathrm{L}$ of the samples amplified through the nested PCR were homogenized with $5.0 \mu \mathrm{L}$ of bromophenol blue, and these were subjected to electrophoresis on $2 \%$ agarose gel with ethidium bromide, in a horizontal sink with a buffer solution of Tris-borate-EDTA (TBE) $1 \mathrm{X}, \mathrm{pH}$ 8.0, for 45 minutes at $120 \mathrm{~V}$. After running the electrophoresis, the amplification products were viewed and photographed by means of a digital photodocumentation system.

\section{Results and Discussion}

This is the first report on detection of the DNA of T. gondii in oysters (Crassostrea sp.) in the state of Maranhão. The molecular analysis on the 160 tissue pools by means of the nested PCR technique amplified the DNA to the expected size of $390 \mathrm{bp}$. The results suggested that molecular detection of this protozoon in the tissue samples only showed its presence in the gill tissues. In total, two pools (2.5\%) of oysters were positive, and both of these came from farming using the "longline" technique (suspended cultivation), in the municipality of Paço do Lumiar.

Positive results through use of the nested PCR technique were also found by Esmerini et al. (2010) in the city of Santos, state of São Paulo, and by Putignani et al. (2011) in Varano Lagoon, Italy. In their investigations on the presence of $T$. gondii in oysters, $3.3 \%$ and $6.6 \%$ of the oysters were found to be positive, respectively.

Precise detection of oocysts of $T$. gondii in samples from the environment is considered to be challenging, even though the nested PCR technique is very sensitive for detecting this protozoon. According to Dumètre \& Dardé (2003), a variety of techniques for breaking oocyst walls exist. These include in vitro excystation, digestion with proteinase K, grinding with glass beads and use of thermal shocks. However, there is no standard protocol for temperatures and the number of cycles of freezing/thawing. In the present study, glass beads were used. This one protocol had some similarity to what was used by Ribeiro et al. (2015), except regarding the use of thermal shocks and addition of protein $\mathrm{K}$. Differences in the procedures used for DNA extraction may have influenced the results that were observed in different studies.

According to Karanis et al. (2013), outbreaks of water-borne transmission of T. gondii started to be documented in the literature in the 1990s. This transmission route added to the many ways in which this protozoon was already known to be disseminated. Thus, on top of the traditionally known infection routes, intake of water contaminated with oocysts took on great importance, given the scientific proof of detection of this protozoon in many aquatic species (Jones \& Dubey, 2010), including bivalve mollusks (Esmerini et al., 2010).

A variety of factors may be involved in identifying zoonotic protozoa in bivalve mollusks. These may include the following: the tissue used (Leal \& Franco, 2008); whether wild and domestic animals are present in the environment where the mollusks are growing (Kváč et al., 2016); and the rainfall rate in relation to lack of basic sanitation (Giangaspero et al., 2014; Sutthikornchai et al., 2016).

Specifically, regarding the tissue used, previous scientific research has shown that the gills of oysters are the best site for investigating occurrences of protozoa (Esmerini et al., 2010; Putignani et al., 2011). This was also observed in the present study.

Regarding the environment in which oysters grow, they reflect the conditions in which they live and thus are considered to be bioindicators for environmental contamination. Therefore, simultaneous cohabitation of several animal species constitutes a potential cause of environmental contamination by $T$. gondii, because of the possibility of flows of residual water containing the feces of the animals to the places where oysters are extracted or farmed. 
This situation was observed in the municipality of Paço do Lumiar: domestic animals such as pigs were being reared in places that were close to where the oysters were being cultivated.

Coastal areas of Brazil are increasingly susceptible to the impacts of human activities, especially with regard to the large quantities of domestic sewage that are discharged without treatment into rivers and the sea (Brasil, 2016). In the state of Maranhão, although water resources are highly available, serious environmental problems have been observed over recent years. The most important indicator of these changes has been discharges of domestic sewage, followed by inadequate disposal of solid waste.

The manner of rearing domestic animals in Paço do Lumiar, as described above, along with a lack of provision of basic sanitation in this municipality, may have been an important factor in the occurrences of $T$. gondii that were detected. Thus, it can be presumed indirectly that the marine environment in which oysters are cultivated in this municipality is contaminated with oocysts of this protozoon. Moreover, it can be suggested that transportation of this protozoon from the terrestrial environment to the marine environment is occurring.

With the results obtained in this study, it can be concluded that: (i) oysters of the genus Crassostrea farmed in the state of Maranhão are capable of filtering the oocysts of $T$. gondii and maintaining them in their tissues, and thus form potential sources of contamination for humans and other animals; (ii) the gills of oysters are the best site for investigating occurrences of this parasite.

\section{Acknowledgements}

To the Pro-Rectorate for Research (PPG) of the State University of Maranhão for awarding the scientific initiation bursary for carrying out this investigation. This study was funded by the Support Foundation for Research and Scientific and Technological Development of the State of Maranhão (FAPEMA).

\section{References}

Brasil. Pesquisa nacional por amostra de domicílios: síntese de indicadores. Rio de Janeiro: IBGE; 2016. 108 p.

Djurković-Djaković O, Dupouy-Camet J, Van der Giessen J, Dubey JP. Toxoplasmosis: overview from a One Health perspective. Food Waterborne Parasitol 2019; 15: e00054. http://dx.doi.org/10.1016/j.fawpar.2019.e00054. PMid:32095624.

Dubey JP. Toxoplasmosis of animals and humans. 2nd ed. Boca Raton: CRC Press; 2010.

Dumètre A, Dardé ML. How to detect Toxoplasma gondii oocysts in environmental samples? FEMS Microbiol Rev 2003; 27(5): 651661. http://dx.doi.org/10.1016/S0168-6445(03)00071-8. PMid:14638417.

Esmerini PO, Gennari SM, Pena HFJ. Analysis of marine bivalve shellfish from the fish market in Santos city, São Paulo state, Brazil, for Toxoplasma gondii. Vet Parasito/ 2010; 170(1-2): 8-13. http://dx.doi.org/10.1016/j.vetpar.2010.01.036. PMid:20197214.

Ferreira EC, Marchioro AA, Guedes TA, Mota DC, Guilherme AL, Araújo SM. Association between seropositivity for Toxoplasma gondii, scholastic development of children and risk factors for T. gondii infection. Trans R Soc Trop Med Hyg 2013; 107(6): 390-396. http://dx.doi.org/10.1093/trstmh/trt026. PMid:23598948.

França VL, Monteles JS, Funo ICSA, Castro ACL. Seleção de áreas potenciais para o cultivo de ostra nativa, Crassostrea spp. e Sururu, Mytella falcata, em Raposa, Maranhão. Arq Ciênc 2013; 46(1): 62-75.

Giangaspero A, Papini R, Marangi M, Koehler A, Gasser RB. Cryptosporidium parvum genotype lla and Giardia duodenalis assemblage A in Mytilus galloprovincialis on sale at local food markets. Int J Food Microbio/ 2014; 171: 62-67. http://dx.doi.org/10.1016/j. ijfoodmicro.2013.11.022. PMid:24334090.

Gyawali P, Hewitt J. Faecal contamination in bivalve molluscan shellfish: can the application of the microbial source tracking method minimise public health risks? Curr Opin Environ Sci Health 2020; 16: 14-21. http://dx.doi.org/10.1016/j.coesh.2020.02.005.

Jones JL, DubeyJP. Waterborne toxoplasmosis: recent developments. Exp Parasito/ 2010; 124(1): 10-25. http://dx.doi.org/10.1016/j. exppara.2009.03.013. PMid:19324041.

Karanis P, Aldeyarbi HM, Mirhashemi ME, Khalil KM. The impact of waterborne transmission of Toxoplasma gondii and analysis efforts for water detection: an overview and update. Environ Sci Pollut Res Int 2013; 20(1): 86-99. http://dx.doi.org/10.1007/ s11356-012-1177-5. PMid:22990578.

Kváč M, Havrdová N, Hlásková L, Daňková T, Kanděra J, Ježková J, et al. Cryptosporidium proliferans n. sp. (Apicomplexa: Cryptosporidiidae): Molecular and biological evidence of cryptic species within gastric Cryptosporidium of mammals. PLoS One 2016; 11(1): e0147090. http://dx.doi.org/10.1371/journal.pone.0147090. PMid:26771460. 
Leal DAG, Franco RMB. Moluscos bivalves destinados ao consumo humano como vetores de protozoários patogênicos: metodologia de detecção e normas de controle. Rev Panam Infectol 2008; 10(4): 48-57.

Lopes RGPS, Antonio IG, Tchaika L, Barros MC, Fraga E. Molecular identification of native oysters on the coast of Maranhão, Brazil. Bol Inst Pesca 2018; 44(4): 377. http://dx.doi.org/10.20950/1678-2305.2018.44.4.377.

Marquis ND, Bishop TJ, Record NR, Countway PD, Fernández Robledo JA. Molecular Epizootiology of Toxoplasma gondii and Cryptosporidium parvum in the Eastern Oyster (Crassostrea virginica) from Maine (USA). Pathogens 2019; 8(3): 125. http://dx.doi. org/10.3390/pathogens8030125. PMid:31412532.

Palos Ladeiro M, Bigot A, Aubert D, Hohweyer J, Favennec L, Villena I, et al. Protozoa interaction with aquatic invertebrate: interest for watercourses biomonitoring. Environ Sci Pollut Res Int 2013; 20(2): 778-789. http://dx.doi.org/10.1007/s11356-012-1189-1. PMid:23001759.

Putignani L, Mancinelli L, Chierico FD, Menichella D, Adlerstein D, Angelici MC, et al. Investigation of Toxoplasma gondii presence in farmed shellfish by nested-PCR and real-time PCR fluorescent amplicon generation assay (FLAG). Exp Parasitol 2011; 127(2): 409-417. http://dx.doi.org/10.1016/j.exppara.2010.09.007. PMid:20920501.

Ribeiro LA, Santos LK, Brito PA Jr, Maciel BM, Silva AV, Albuquerque GR. Detection of Toxoplasma gondii DNA in Brazilian oysters (Crassostrea rhizophorae). Genet Mol Res 2015; 14(2): 4658-4665. http://dx.doi.org/10.4238/2015.May.4.25. PMid:25966240.

Souza DSM, Ramos APD, Nunes FF, Moresco V, Taniguchi S, Guiguet Leal DA, et al. Evaluation of tropical water sources and mollusks in southern Brazil using microbiological, biochemical and chemical parameters. Ecotoxicol Environ Saf 2012; 76(2): 153161. http://dx.doi.org/10.1016/j.ecoenv.2011.09.018. PMid:22036209.

Sutthikornchai C, Popruk S, Chumpolbanchorn K, Sukhumavasi W, Sukthana Y. Oyster is an effective transmission vehicle for Cryptosporidium infection in human. Asian Pac J Trop Med 2016; 9(6): 562-566. http://dx.doi.org/10.1016/j.apjtm.2016.04.018. PMid:27262067. 